\title{
Fanconi Anemia Mouse Genotype-specific Mitigation of Total Body Irradiation by GS-Nitroxide JP4-039
}

\author{
MICHAEL W. EPPERLY ${ }^{1}$, RENEE FISHER ${ }^{1}$, XICHEN ZHANG ${ }^{1}$, WEN HOU ${ }^{1}$, DONNA SHIELDS ${ }^{1}$, \\ PETER WIPF $^{2}$, HONG WANG $^{3}$, STEPHANIE THERMOZIER $^{1}$ and JOEL S. GREENBERGER ${ }^{1}$ \\ ${ }^{1}$ Department of Radiation Oncology, UPMC Hillman Cancer Center, Pittsburgh, PA, U.S.A.; \\ ${ }^{2}$ Department of Chemistry, University of Pittsburgh, Pittsburgh, PA, U.S.A.; \\ ${ }^{3}$ Department of Biostatistics, University of Pittsburgh, Pittsburgh, PA, U.S.A.
}

\begin{abstract}
Background/Aim: Radiation mitigator, GSnitroxide, JP4-039, was evaluated for mitigation of total body irradiation (TBI) in Fanconi anemia (FA) Fancd2 ${ }^{-/-}$ (129/Sv), Fancg ${ }^{-/-}(B 6)$, and Fanca ${ }^{-/-}(129 / S v)$ mice. Materials and Methods: JP4-039 dissolved in 30\% 2hydroxypropyl- $\beta$-cyclodextrin was injected intramuscularly 24 h after total body irradiation (9.25 Gy) into Fanca $^{-/-}$, Fancd $2^{-/-}$and Fancg $^{-1-}$ mice. Irradiation survival curves were performed in vitro using bone marrow stromal cell lines derived from $\mathrm{Fanca}^{-/-}$, Fancd2 $^{-/-}$and $\mathrm{Fancg}^{-/-}$mice. Results: FA mice demonstrate genotype specific differences in TBI mitigation by JP4-039. Radiation effects in derived bone marrow stromal cell lines in vitro were mitigated by drugs that block apoptosis, but not necroptosis or ferroptosis. Conclusion: FA mouse models are valuable for elucidating DNA repair pathways in cell and tissue responses to TBI, and the role of drugs that target distinct cell death pathways.
\end{abstract}

Fanconi anemia (FA) represents a disease associated with defect in one or more of the 26 genes involved in the scaffold of proteins that facilitate binding and activity of DNA double strand break repair enzymes (1-3). Patients with FA, as well as mouse models of FA, demonstrate radiosensitivity of explanted bone marrow stromal cells in vitro (1-4).

The mitochondrial targeted radiation mitigator GS-nitroxide, JP4-039, has been demonstrated to significantly ameliorate the effects of total body irradiation (TBI) of several

This article is freely accessible online.

Correspondence to: Joel S. Greenberger, MD, F.A.C.R.O., F.A.C.R., F.A.S.T.R.O., UPMC Hillman Cancer Center, UPMC Cancer Pavilion, Rm. 533, 5150 Centre Avenue, Pittsburgh, PA 15232, U.S.A. Tel: +1 4126473602, Fax: +1 4126476029, e-mail: greenbergerjs@upmc.edu

Key Words: Fanconi Anemia, genotype, JP4-039, total body irradiation. mouse strains when delivered systemically up to $72 \mathrm{~h}$ after (511). Furthermore, in organ-specific radiation protection and mitigation experiments including the oral cavity, mice of three different genotypes on two different mouse background strains with DNA repair-deficient FA revealed therapeutic effects of JP4-039 (1-3, 12-19). Radiation dose-response curves showed significant reduction in colony formation in vitro and a radiation-protective effect of JP4-039 in bone marrow stromal and hematopoietic progenitor cell lines as well as fresh bone marrow colony-forming progenitor cells consistent with FA genotype mouse genotype (1-3, 12, 15).

In the present studies, we evaluated the response to TBI with mice of each FA genotype, as well as wild-type littermates, using the TBI dose lethal for $50 \%$ of mice at 30 days $\left(\mathrm{LD}_{50 / 30}\right)$. In these experiments, we looked at mitigation of irradiation damage as reflected in increased survival following irradiation by drugs that block apoptosis, necroptosis or ferroptosis.

\section{Materials and Methods}

Mice and animal care. Fanca ${ }^{-/}$(129/Sv background) (3), Fancg-/(C57BL/6J background) (3), and Fancd2-/- (C57BL/6J (2) or 129/Sv background) (1) mice were maintained at four mice per cage, according to University of Pittsburgh Institutional Animal Care and Use Committee regulations. The breeding genotyping of FA mice of each genotype, as well as normal control littermates from each breeding have been described previously (1-3). Serpinb $3 a^{-/-}$and Balb/c control littermates were bred and maintained according to published methods (20).

TBI. Mice received the $\mathrm{LD}_{50 / 30}$ dose of TBI for each background mouse strain using a cesium137 irradiator (JL Shepherd, San Fernando, CA, USA). The dose of TBI delivered was $8.5 \mathrm{~Gy}$. This dose was shown to be the $\mathrm{LD}_{50 / 30}$ dose for FA mice and is consistent with the known differences in radiosensitivity of FA mice (1-3).The conditions for irradiation at $310 \mathrm{cGy} / \mathrm{min}$, with filters removed from the cesium irradiator, and dosimetry carried out to ensure uniform dose distribution in mouse phantoms are described elsewhere (18). Conditions for irradiation using a pie-plate animal separator, and specific slots for irradiation, ensuring uniform dose distribution between animals are described therein. 


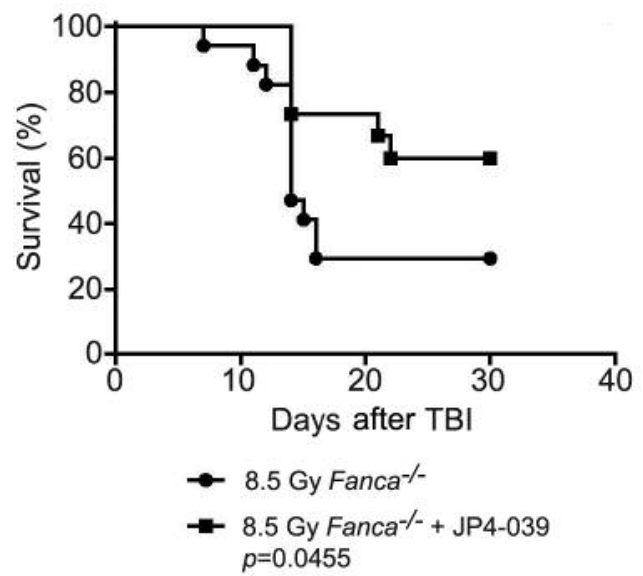

Figure 1. Total body irradiation (TBI) mitigation by JP4-039 in $\mathrm{Fanca}^{-/-}$ mice. Thirty-four Fanca-l- mice (129/Sv background) were irradiated to 8.5 Gy TBI. Seventeen of the mice were injected with JP4-039 $(20 \mathrm{mg} / \mathrm{kg}$ dissolved at $8 \mathrm{mg} / \mathrm{ml}$ in 30\% 2-carboxypropy- $\beta$-cyclodextrin) $(50 \mu \mathrm{l}) 24$ $h$ after irradiation. The mice were followed for development of hematopoietic syndrome at which time they were sacrificed. Mice injected with JP4-039 had significantly increased survivaI.

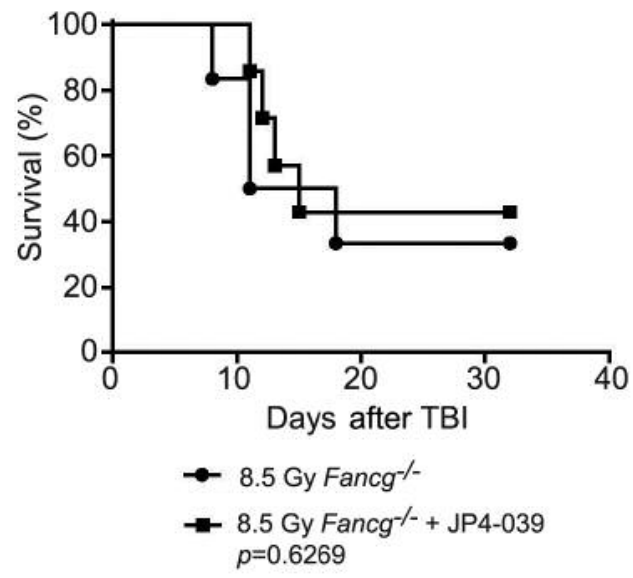

Figure 2. Lack of total body irradiation (TBI) mitigation by JP4-039 in

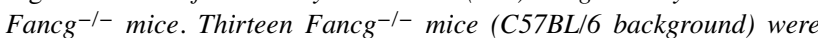
irradiated to 8.5 Gy TBI. Twenty-four hours later, seven of the mice were injected with $50 \mu \mathrm{l}$ of JP4-039 dissolved in 30\% 2-hydroxypropyl- $\beta$ cyclodextrin at a concentration of $8 \mathrm{mg} / \mathrm{ml}$. The mice were followed for the development of hematopoietic syndrome at which time they were sacrificed. There was no significant difference in survival between the groups.

Radiation mitigator drugs and administration. JP4-039 (provided by Dr. Peter Wipf of the University of Pittsburgh) (18) was dissolved in $30 \%$ 2-hydroxypropyl- $\beta$-cyclodextrin (Sigma-Aldrich, St. Louis, MO, USA) at $8 \mathrm{mg} / \mathrm{ml}$ and $50 \mu \mathrm{l}$ was injected intramuscularly to give a final concentration of $20 \mathrm{mg} / \mathrm{kg}$. For in vitro studies, JP4-039, necrostatin-1 (Sigma-Aldrich, St. Louis, MO, USA), and baicalein (Cayman Chemical, Ann Arbor, MI, USA) were dissolved in

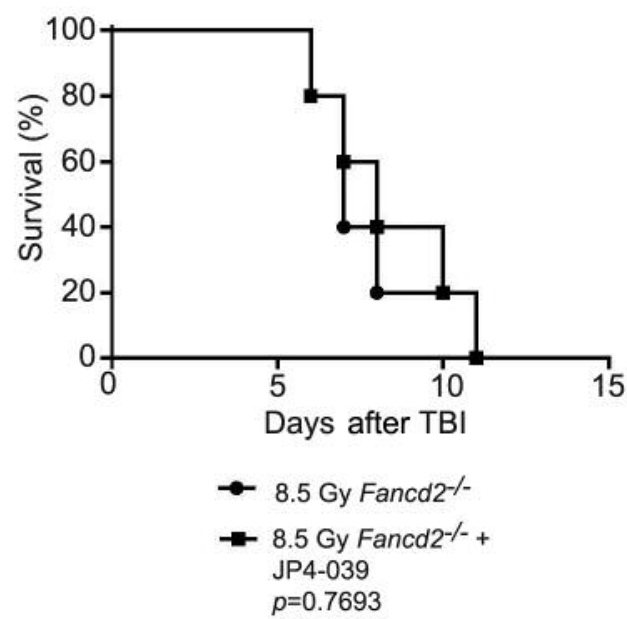

Figure 3. Lack of total body irradiation (TBI) mitigation by JP4-039 in Fancd2-l- mice. Ten Fancd2-l- on a 129/Sv background were irradiated to $8.5 \mathrm{~Gy} \mathrm{TBI}$, and five were injected $(50 \mu \mathrm{l}) 24 \mathrm{~h}$ later with JP4-039 $(20 \mathrm{mg} / \mathrm{kg})$ in 30\% 2-hydroxypropyl- $\beta$-cyclodextrin $(8 \mathrm{mg} / \mathrm{ml})$. The mice were followed for development of hematopoietic syndrome. There was no significant difference in survival between the groups.

dimethyl sulfoxide at $10 \mathrm{mM}$, and then diluted 1:1000 in tissue culture medium for a final concentration of $10 \mu \mathrm{M}$ for each drug.

Bone marrow stromal cell line irradiation and clonogenic survival curve analysis. Bone marrow stromal cell lines from each FA genotype and control littermates were passaged and cultured according to previous publications (1-3). The effect of JP4-039 (10 mM), necrostatin-1 $(10 \mathrm{mM})$ or baicalein $(10 \mathrm{mM})$ was tested by adding the drug to single-cell suspensions of each cell line immediately before irradiation. Cells were irradiated to doses between 0 and $8 \mathrm{~Gy}$ in conical centrifuge tubes according to previous publications (1-3). Cells were plated in Dulbecco's modified Eagle's medium for clonogenic survival assay at densities of between 500 and 3,000 cells per $\mathrm{ml}$. Quadruplicate cultures were plated for each cell density. Cells and cultures were incubated in a high humidity incubator with $7 \% \mathrm{CO}_{2}$ for 7-10 days after which time the colonies were stained with crystal violet. Colonies of greater than 50 cells were scored according to published methods (8). The calculation of the irradiation dose that reduced survival to $37 \%$ on the exponential portion of the survival curve $\left(\mathrm{D}_{0}\right)$ and the extrapolation number of the linear portion of the survival curve to the y axis ( $\tilde{\mathrm{n}})$ was carried out according to previous publication (8).

Statistics. In vitro irradiation survival curves were analyzed using linear quadratic and single-hit multi-target models. Comparisons of $\mathrm{D}_{0}$ and $\tilde{\mathrm{n}}$ were performed with an Unpaired $t$-test. In vivo irradiation survival curves were analyzed using a log-rank test.

\section{Results}

Mitigation of effects of TBI by JP4-039 in $\mathrm{Fanca}^{-/-}$mice. Groups of $\mathrm{Fanca}^{-/-}$and control 129/Sv littermates (Figure 1), Fancg $^{-/-}$mice and control C57BL/6 littermates (Figure 2), 

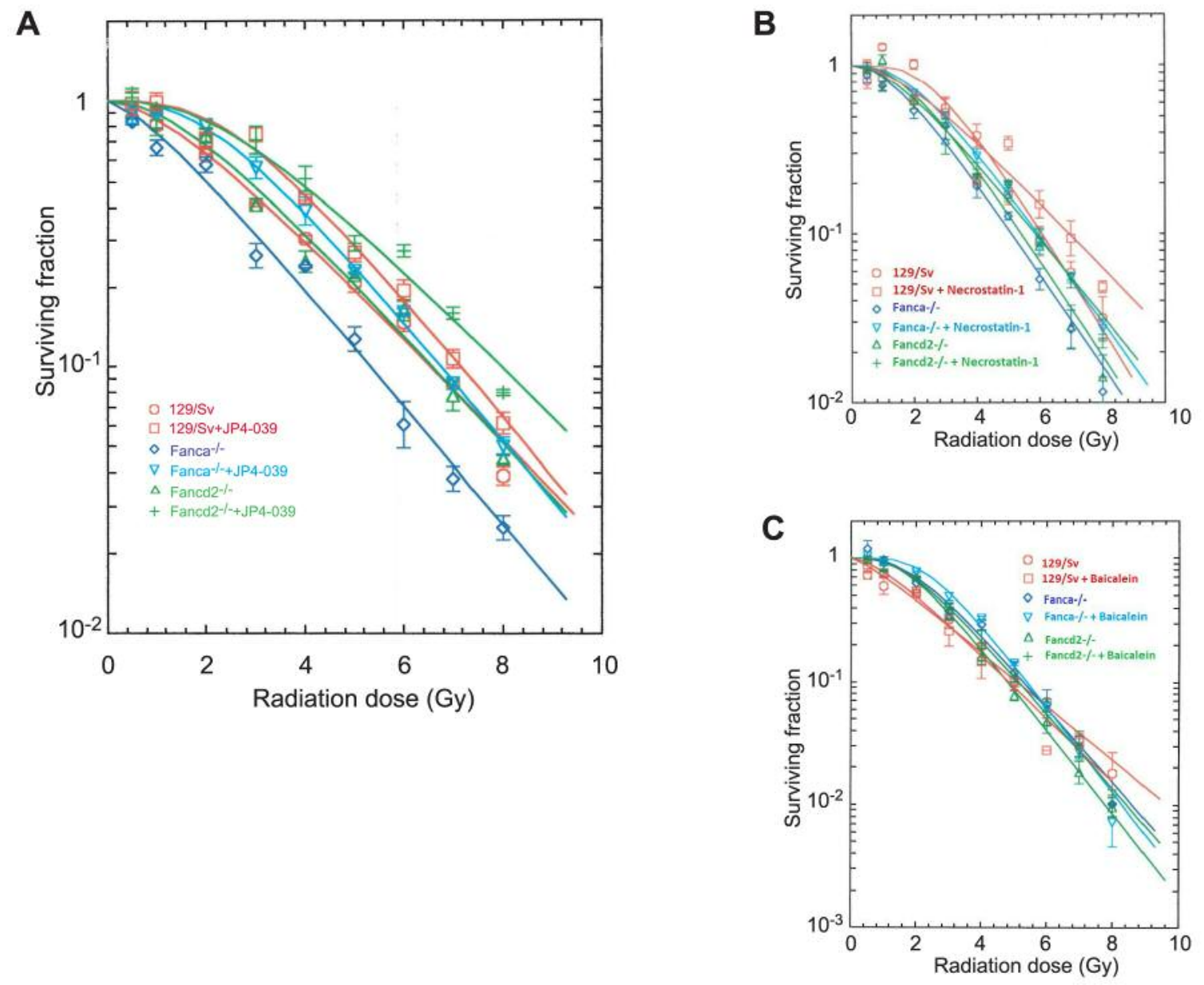

Figure 4. Radiosensitivity of Fanconi anemia cell lines is mitigated by JP4-039, but not by necrostatin-1 or baicalein. Mitigation by JP4-039 of radiation damage was detected in 129/Sv, Fanca-l-, and Fancd $2^{-1-}$ bone marrow stromal cells (A). In contrast, necrostatin-1 (B) or baicalein $(C)$ mitigated irradiation damage in the 129/Sv cell line, but not the Fanca ${ }^{-1-}$ or the Fancd2-/- cell lines.

and Fancd $2^{-/-}$and control 129/Sv littermates (Figure 3) were irradiated to the $\mathrm{LD}_{50 / 30}$ dose of TBI.

Fanca $^{-/-}$mice that received JP4-039 24 h after TBI survived significantly longer than those that did not (Figure 1). In contrast, in $\mathrm{Fancg}^{-/-}$(Figure 2) and Fancd2-/- (Figure 3) mice, JP4-039 demonstrated no significant radiation mitigation and survival was not improved. JP4-039 demonstrated significant mitigation in normal littermate control strains on both the 129/Sv and C57BL/6J B6 (8) background. These results establish that there are genotypic differences in FA mice with respect to TBI mitigation by JP4-039.

JP4-039 induces significant radioresistance in bone marrow stromal cell lines from FA mice. To determine whether differences in TBI response to JP4-039 were seen with irradiation of cell lines in vitro, bone marrow stromal cell lines of each genotype and control littermate were treated with JP4-039 in vitro immediately after irradiation to doses of 0 to $8 \mathrm{~Gy}$. Colony formation by irradiated cells in continuous presence of JP4-039 over 7 days in culture was scored. As shown in Figure 4A, JP4-039 significantly mitigated the effects of radiation in all cell lines (Table I).

These results establish that in vitro, JP4-039 was radiationprotective and -mitigating in bone marrow stromal cell lines derived from mice of two different FA genotypes. These results are in contrast to the in vivo mitigation by JP4-039 at $24 \mathrm{~h}$ after TBI which was observed only in $\mathrm{Fanca}^{-/-}$mice.

Lack of detectable radiation mitigation by necrostatin-1 and baicalein in FA mouse marrow stromal cell lines. Using clonogenic irradiation survival curves, we tested the anti-necroptosis drug necrostatin-1, and the anti-ferroptosis drug baicalein to determine whether $\mathrm{FanCa}^{-/-}$and $\mathrm{FanCd}^{-/-}$bone marrow stromal cells were able to modulate the irradiation dose 
Table I. Radioprotection of Fanconi anemia bone marrow stromal cell lines by small molecule drugs JP4-039, baicalein, and necrostatin-1. 129/Sv control, Fanca ${ }^{-1}$ and Fancd $2^{-1-}$ bone marrow stromal cell lines were used in irradiation survival curves. JP4-039, baicalein (10 $\left.\mu M\right)$ and necrostatin-1 $(10 \mu \mathrm{M})$ were added $1 \mathrm{~h}$ before irradiation, and cells were then kept in culture for 7 days. The cells were stained with crystal violet and colonies greater than 50 cells counted. The data were analyzed using single-hit, multi-target or linear quadratic models. Significant p-values are shown.

\begin{tabular}{|c|c|c|c|c|c|c|c|c|c|c|c|}
\hline \multirow[t]{2}{*}{ Cell line } & \multicolumn{2}{|c|}{ Control } & \multicolumn{2}{|c|}{ Baicalein } & \multirow[b]{2}{*}{$p$-Value* } & \multicolumn{2}{|c|}{ Necrostatin-1 } & \multicolumn{4}{|c|}{ JP4-039 } \\
\hline & $\mathrm{D}_{0}$ & $\tilde{\mathrm{n}}$ & $\mathrm{D}_{0}$ & $\tilde{\mathrm{n}}$ & & $\mathrm{D}_{0}$ & $\tilde{\mathrm{n}}$ & $p$-Value* & $\mathrm{D}_{0}$ & $\tilde{\mathrm{n}}$ & $p$-Value* \\
\hline $129 / \mathrm{Sv}$ & $1.92 \pm 0.16$ & $5.1 \pm 1.2$ & $1.75 \pm 0.11$ & $11.8 \pm 2.7$ & 0.0493 & $1.66 \pm 0.14$ & $12.7 \pm 0.15$ & 0.0122 & $2.87 \pm 0.12$ & $4.7 \pm 0.11$ & 0.0444 \\
\hline Fanca $^{-/-}$ & $1.77 \pm 0.11$ & $3.2 \pm 0.4$ & $1.84 \pm 0.21$ & $3.3 \pm 0.6$ & & $1.65 \pm 0.07$ & $3.7 \pm 0.4$ & & $3.10 \pm 0.25$ & $3.9 \pm 0.3$ & 0.0444 \\
\hline Fancd2-/- & $2.21 \pm 0.09$ & $1.9 \pm 0.2$ & $1.82 \pm 0.09$ & $2.5 \pm 0.3$ & & $2.01 \pm 0.09$ & $2.8 \pm 0.5$ & & $2.73 \pm 0.10$ & $5.1 \pm 2.0$ & 0.0237 \\
\hline
\end{tabular}

*For $\mathrm{D}_{0}$ vs. Control.

response. Each cell line was treated with each drug and evaluated in clonogenic survival assays. The results demonstrated no detectable mitigation by necrostatin-1 or baicalein for any of the FA bone marrow stromal cell lines of each genotype (Table I; Figure 4B and C). In contrast, necrostatin-1, or baicalein Ied to significant radiation mitigation in bone marrow stromal cell lines derived from control littermate (Table I). These results established that $\mathrm{FanCa}^{-/-}$and $\mathrm{FanCd}^{-/-}$bone marrow stromal cell lines did not have increased radiation resistance when incubated with anti-necroptosis drug, necrostatin-1, and the anti-ferroptosis drug, baicalein.

Gene deletion does not always result in increased radiation sensitivity. As a control experiment, we determined whether homologous recombinant deletion of another gene product accounted for the radiosensitivity of the FA mouse strains tested. As a control for the radiosensitivity of $\mathrm{Fanca}^{-/-}, \mathrm{Fancg}^{-/-}$ and Fancd $2^{-/-}$mice, we carried out TBI with a third background strain of radiosensitive Balb/c mice, and a genotypic variant (Serpinb3a $a^{-/}$) (20) (Figure 5). In contrast to the data for FA mice, homologous recombinant negative Serpinb3a $a^{-/-}$ mice exhibited radioresistance (Figure 5). Thus, homologous recombinant deletion of a gene does not uniformly produce the phenotype of radiosensitivity to TBI.

\section{Discussion}

There are multiple cell death pathways initiated by exposure of cell lines, tissues, and organs to TBI $(1,20)$. Radiation mitigator drugs delivered $24 \mathrm{~h}$ after irradiation, which target each of three cell death pathways (apoptosis, necroptosis, and ferroptosis), have been demonstrated to be more effective in increasing survival after TBI than the delivery of one mitigator or administration of two mitigators (18). Those studies also indicated that in TBI, the time of delivery of mitigators targeted to each cell death pathway would be optimized by identification of the biochemical targets for each drug (18).
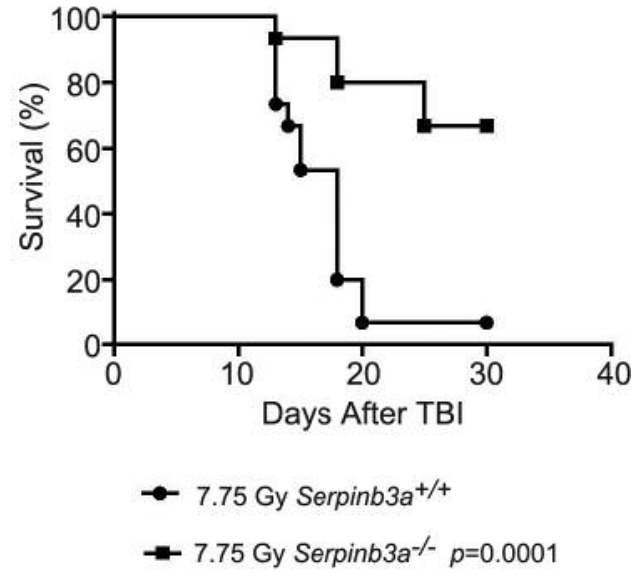

Figure 5. Radiation mitigation in Serpinb3a-1- mice compared to control Balb/c littermates. Fifteen Balb/c (Serpinb3 $3^{+/+}$) and 15 Serpinb3a-1mice received total body irradiation to $7.75 \mathrm{~Gy}$, and were followed up for development of hematopoietic syndrome at which time they were sacrificed. Serpinb3a-1- mice had significantly increased survival.

To effectively mitigate against irradiation-induced apoptosis, JP4-039 was shown to be optimal when delivered at $24 \mathrm{~h}$ after TBI, although waves of apoptosis were still detectable up to $72 \mathrm{~h}$, and delivery of this mitigator at that time was still effective (6). In contrast, necrostatin-1, a drug which targets necroptosis, was shown to be ineffective until delivered at the delayed time point of $48 \mathrm{~h}$ after TBI, and was associated with detectable up-regulation of tumor necrosis factor- $\alpha$ and interleukin-1, which represent biochemical markers for the initiation of necroptosis (18). Furthermore, the phosphorylation of receptor-interacting serine/threonine-protein kinase 3 in bone marrow and tissues was shown to be detectable at $48 \mathrm{~h}$ after TBI, but not earlier, and consistent with the optimal time of delivery of necrostatin-1.

A third cell death pathway, ferroptosis (21), has been shown to be initiated when the level of glutathione peroxidase-4 
(mitochondrial active antioxidant) decreased, and when the acyl-CoA-synthase marker for the oxidized lipid changes associated with ferroptosis increased. Of three drugs known to block ferroptosis, baicalein was found to be the optimal mitigator for this cell death pathway, and best delivered at $24 \mathrm{~h}$ after TBI along with the anti-apoptosis drug, JP4-039 (18).

In the present experiments both background strain mice, $129 / \mathrm{Sv}$ and C57BL/6J, as well as their derived bone marrow stromal cell lines were radioresistant when treated with JP4039. Furthermore, irradiation was also mitigated in control mouse cell lines in vitro by necrostatin-1 and baicalein. We tested whether radiation mitigators were also effective against TBI in FA mice.

Mice with FA of two different background strains and different genotypes were tested for amelioration of TBI-induced hematopoietic syndrome, using a dose of irradiation that is rescuable by bone marrow transplantation and by delivery of the anti-apoptotic drug, JP4-039. The results demonstrated that JP4-039 protected from TBI in $\mathrm{Fanca}^{-/-}$but not $\mathrm{Fancg}^{-/-}$ or Fancd $2^{-/-}$mice. The difference in TBI radiation mitigation by JP4-039 according to FA genotype was in contrast to the uniform in vitro radiation protection observed in bone marrow stromal cell lines from each genotype.

The present data are consistent with the model in which different cell phenotypes in tissues of mice, including bone marrow hematopoietic cells, intestinal stem cells, and cells of the liver and lung, may account for the radiosensitivity to TBI that is not ameliorated by systemic delivery of JP4-039 $(12,18)$. In contrast to the data with FA mice, in wild-type littermates of each FA genotype, uniform radiation mitigation was induced by necrostatin-1 and baicalein, as well as JP4-039. The data are also consistent with the notion that different cell populations within tissues in some FA genotypes may be radiosensitive $(12,22)$. The results support the non-uniform response of patients with FA to total or partial body irradiation used to prepare individuals for bone marrow transplantation. Results with different FA genotypes with respect to TBI sensitivity and amelioration by JP4-039 are consistent with other studies showing genotype specific differences in TBI sensitivity and known relative radioresistance of female compared to male mice $(23,24)$, and between mouse strains $(25)$.

The present studies establish the relative ineffectiveness of radiation mitigators targeting necroptosis (necrostatin-1) or ferroptosis (baicalein) (18) in cell lines from FA mice, while there was significant radiation protection/mitigation by the same drugs in control bone marrow stromal cell lines. These mouse models of FA should prove valuable for studies of the mechanisms of radiation toxicity and amelioration by drugs that target distinct cell death pathways.

\section{Conflicts of Interest}

There are no conflicts of interest.

\section{Authors' Contributions}

Michael W. Epperly aided in the experimental design, irradiation, and analysis of data. Renee Fisher aided in the breeding of the mice, irradiation of the mice and drug administration. Xichen Zhang was responsible for maintaining the cells in vitro. Wen Hou aided in the survival curves and genotyping of the pups. Donna Shields prepared the in vitro survival curves. Peter Wipf made the JP4-039 while Hong Wang performed the statistical analysis. Stephanie Thermozier aided in the Serapinb3a-l- mouse experiments. Joel S. Greenberger participated in the experimental design and data analysis.

\section{Acknowledgements}

This study was supported by grant from the NIH/NIAID U19A168021, and the UPCI-Hillman Animal Research Core Facility award P30CA047904.

\section{References}

1 Berhane H, Shinde A, Kalash R, Xu K, Epperly MW, Goff J, Franicola D, Zhang X, Dixon T, Shields D, Wang H, Wipf P, Li S, Gao X and Greenberger JS: Amelioration of irradiation induced oral cavity mucositis and distant bone marrow suppression in Fancd 2-/- (FVB/N) mice by intraoral JP4-039/F15. Radiat Res 182: 35-49, 2014. PMID: 24932534. DOI: 10.1667/RR13633.1

2 Shinde A, Berhane H, Rhieu BH, Kalash R, Xu K, Goff J, Epperly MW, Franicola D, Zhang X, Dixon T, Shields D, Wang H, Wipf P, Parmar K, Ferris R, Li S and Greenberger JS: Intraoral mitochondrial-targeted GS-nitroxide, JP4-039, radioprotects normal tissue in tumor-bearing radiosensitive Fancd2-/- (C57BL/6) mice. Radiat Res 185: 134-150, 2016. PMID: 26789701. DOI: 10.1667/RR14035.1

3 Willis J, Epperly MW, Fisher R, Zhang X, Shields D, Hou W, Wang H, Li S, Wipf P, Parmar K, Guinan E, Steinman J and Greenberger JS: Amelioration of head and neck irradiationinduced mucositis and distant marrow suppression in $\mathrm{Fanca}^{-/-}$ and $\mathrm{Fanc}^{-/-}$mice by intraoral administration of GS-nitroxide (JP4-039). Radiat Res 189: 560-578, 2018. PMID: 29584588. DOI: $10.1667 / R R 14878.1$

4 Quinn TJ, Ding X, Li X, Wilson GD, Buelow K, Sivananthan A, Thermozier S, Henderson A, Epperly MW, Franicola D, Wipf P, Greenberger JS, Stevens CW and Kabolizadeh P: Amelioration of mucositis in proton therapy of fanconi anemia $\mathrm{Fanca}^{-/}$mice by JP4-039. In Vivo 33(6): 1757-1766, 2019. PMID: 31662500. DOI: 10.21873/invivo.11666

5 Fink M, Macias CA, Xiao J, Tyurina YY, Delude RL, Greenberger JS, Kagan VE and Wipf P: Hemigramicidin-TEMPO conjugates: Novel mitochondria-targeted antioxidants. Crit Care Med 35(9): 5461-5470, 2007. PMID: 17713394. DOI: 10.1097/01.CCM. 0000279192.96303.E7

6 Jiang J, Belikova NA, Xiao J, Zhao Q, Greenberger JS, Wipf P and Kagan VE: A mitochondria-targeted nitroxide/hemi-gramicidin $\mathrm{S}$ conjugate protects mouse embryonic cells against $\square$-irradiation. Int J Radiat Oncol Biol Phys 70(3): 816-825, 2008. PMID: 18262096. DOI: 10.1016/j.ijrobp.2007.10.047

7 Kagan VE, Bayir A, Bayir H, Stoyanovsky D, Borisenko GG, Tyurina YY, Wipf P, Atkinson J, Greenberger JS, Chapkin RS and Belikova NA: Mitochondria-targeted disruptors and inhibitors of 
cytochrome c/cardiolipin peroxidase complexes: A new strategy in anti-apoptotic drug discovery. Mol Nutr Food Res 53: 104-114, 2009. PMID: 18979502 . DOI: $10.1002 / \mathrm{mnfr} .200700402$

8 Rwigema J-CM, Beck B, Wang W, Doemling A, Epperly MW, Shields D, Franicola D, Dixon T, Frantz M-C, Wipf P, Tyurina Y, Kagan VE, Wang $\mathrm{H}$ and Greenberger JS: Two strategies for the development of mitochondrial-targeted small molecule radiation damage mitigators. Int J Radiat Oncol Biol Phys 80(3): 860-868, 2011. PMID: 21493014. DOI: 10.1016/j.jjrobp.2011.01.059

9 Kim H, Bernard ME, Epperly MW, Shen H, Amoscato A, Dixon TM, Doemling AS, Li S, Gao X, Wipf P, Wang H, Zhang X, Kagan VE and Greenberger JS: Amelioration of radiation esophagitis by orally administered p53/MDM2/MDM4 inhibitor (BEB55) or GSnitroxide. In Vivo 25(6): 841-849, 2011. PMID: 22021675

10 Greenberger JS, Clump D, Kagan V, Bayir H, Lazo J, Wipf P, Li S, Gao X and Epperly MW: Strategies for discovery of small molecule radiation protectors and radiation mitigators. Front Radiat Oncol 1: 59, 2012. PMID: 22655254. DOI: 10.3389/fonc.2011.00059

11 Goff J, Shields D, Wang H, Skoda E, Sprachman M, Wipf P, Lazo J, Atkinson J, Kagan V, Epperly $M$ and Greenberger JS: Evaluation of potential ionizing irradiation protectors and mitigators using clonogenic survival of human umbilical cord blood hematopoietic progenitor cells. Exp Hematol 41(11): 957-966, 2013. PMID: 23933481. DOI: 10.1016/j.exphem.2013.08.001

12 Berhane H, Epperly MW, Goff J, Kalash R, Cao S, Franicola D, Zhang X, Shields D, Houghton F, Wang H, Sprachman M, Wipf P, Li S, Gao X, Parmar K and Greenberger JS: Radiobiologic differences between bone marrow stromal and hematopoietic progenitor cell lines from Fanconi anemia (Fancd $2^{-/}$) mice. Radiat Res 181: 76-89, 2014. PMID: 24397476. DOI: 10.1667/RR13405.1

13 Tyurina YY, Poloyac SM, Tyurin VA, Kapralov AA, Jiang J, Anthonymuthus TS, Kapralova VI, Vikulina AS, Jung M-J, Epperly MW, Mohammadyani D, Klein-Seetharaman J, Jackson TC, Rochanek PM, Pitt BR, Greenberger JS, Vladimirov YA, Bayir $\mathrm{H}$ and Kagan VE: A mitochondrial pathway for biosynthesis of lipid mediators. Nat Chem 6(6): 542-552, 2014. PMID: 24848241. DOI: $10.1038 /$ nchem.1924

14 Greenberger JS, Berhane H, Shinde A, Rhieu BH, Bernard M, Wipf P, Skoda EM and Epperly MW: Can radiosensitivity associated with defects in DNA repair be overcome by mitochondrialtargeted antioxidant radioprotectors? Front Radiat Oncol 4: 24, 2014. PMID: 24596683. DOI: 10.3389/fonc.2014.00024

15 Shinde A, Epperly MW, Franicola D, Cao S, Goff J, Shields D, Wipf P, Wang H and Greenberger JS: Improved hematopoiesis in GS-nitroxide (JP4-039)-treated mouse long-term bone marrow cultures and radioresistance of derived bone marrow stromal cell lines. In Vivo 28(5): 699-708, 2014. PMID: 25189880

16 Brand R, Epperly MW, Stottlemyer JM, Skoda E, Gao X, Li S, Huq S, Wipf P, Kagan VE, Greenberger JS and Falo LD Jr.: A topical mitochondria-targeted redox cycling nitroxide mitigates oxidative stress induced skin damage. J Invest Dermatol 137(3): 576586, 2017. PMID: 27794421. DOI: 10.1016/j.jid.2016.09.033

17 Epperly MW, Sacher JR, Krainz T, Zhang X, Wipf P, Liang M, Fisher R, Li S, Wang H and Greenberger JS: Effectiveness of analogues of the GS-nitroxide, JP4-039, as total body radiation mitigators. In Vivo 31: 39-44, 2017. PMID: 28064218. DOI: 10.21873/invivo.11022
18 Steinman J, Epperly M, Hou W, Willis J, Wang H, Fisher R, Liu B, Bahar I, McCaw T, Kagan V, Bayir H, Yu J, Wipf P, Li S, Huq MS and Greenberger JS: Improved total-body irradiation survival by delivery of two radiation mitigators that target distinct cell death pathways. Radiat Res 189(1): 68-83, 2018. PMID: 29140165. DOI: 10.1667/RR14787.1

19 Epperly MW, Wipf P, Fisher R, Franicola D, Beumer J, Li S, Brand R, Falo L and Greenberger JS: Evaluations of different formulations and routes for the delivery of the ionizing radiation mitigation GS-nitroxide (JP4-039). In Vivo 32: 1009-1023, 2018. PMID: 30150422. DOI: 10.21873/invivo.11341

20 Thermozier S, Zhang X, Hou W, Fisher R, Epperly MW, Liu B, Bahar I and Greenberger JS: Radioresistance of Serpinb3a-/mice and derived hematopoietic and marrow stromal cell lines. Radiat Res 192(3): 267-281, 2019. PMID: 31295086. PMID: 31295086. DOI: $10.1667 /$ RR15379.1

21 Dar HH, Tyurina YY, Mikulska KA, Shrivastava I, Tyurin VA, Krieger J, St. Croix C, Watkins S, Bayir E, Ting H-C, Mao G, Ogunsola AF, Flitter BA, Freedman C, Gaston JR, Holman T, Pilewski J, Greenberger JS, Mallampalli R, Bahar I, Bomberger J, Bayir $\mathrm{H}$ and Kagan VE: Pseudomonas aeruginosa utilizes host polyunsaturated phosphatidylethanolamines to trigger theft-ferroptosis in bronchial epithelium. J Clin Invest 128(10): 46394653, 2018. PMID: 30198910. DOI: $10.1172 / J C 199490$

22 Bernard ME, Kim H, Berhane H, Epperly MW, Franicola D, Zhang X, Houghton F, Shields D, Wang H, Bakkenist CJ, Frantz M-C, Wipf P and Greenberger JS: GS-nitroxide (JP4-039) mediated radioprotection of human Fanconi anemia cell lines. Radiat Res 176: 603-612, 2011. PMID: 21939290. DOI: 10.1667/rr2624.1

23 Epperly MW, Smith T, Wang H, Schlesselman J, Franicola D and 3Greenberger JS: Modulation of total body irradiation induced life shortening by systemic intravenous MnSOD-plasmid liposome gene therapy. Radiat Res 170(4): 437-444, 2008. PMID: 19024650. DOI: $10.1667 / \mathrm{rr} 1286.1$

24 Epperly MW, Wang H, Jones J, Dixon T, Montesinos C and Greenberger JS: Antioxidant-chemoprevention diet ameliorates late effects of total body irradiation and supplements radioprotection by MnSOD-plasmid liposome administration. Radiat Res 175: 759-765, 2011. PMID: 21466381. DOI: 10.1667/RR2398.1

25 Kalash R, Berhane H, Goff J, Houghton F, Epperly MW, Dixon T, Zhang X, Sprachman MM, Wipf P, Franicola D, Wang H and Greenberger JS: Thoracic irradiation effects on pulmonary endothelial compared to alveolar type II cells in fibrosis-prone C57BL/6NTac mice. In Vivo 27: 291-298, 2013. PMID: 23606683 . 